\title{
Green Synthesis and Characterization of Copper Nanoparticles and Their Effects on Liver Function and Hematological Parameters in Mice
}

\author{
Bakır Nanopartiküllerinin Yeşil Sentezi, Karakterizasyonu, Farelerde \\ Karaciğer İşlevi ve Hematolojik Parametreler Üzerine Etkileri
}

\author{
(D) Mehrdad KHATAMI ${ }^{1}$, (D) Katrin EBRAHIMI2, (D) Nasrin GALEHDAR ${ }^{3}$, (D) Mohammad Nabi MORADI ${ }^{4}$, (D) Alireza MOAYYEDKAZEMI5* \\ 1Student Research Committee, Bam University of Medical Sciences, Bam, Iran \\ 2Department of Biology, Payame Noor University, Tehran, Iran \\ 3Social Determinants of Health Research Center, Lorestan University of Medical Sciences, Khorramabad, Iran \\ ${ }^{4}$ Razi Herbal Medicines Research Center, Lorestan University of Medical Sciences, Khorramabad, Iran \\ 5Department of Internal Medicine, Lorestan University of Medical Sciences, Khorramabad, Iran
}

\begin{abstract}
Objectives: The present investigation is based on the green synthesis of copper nanoparticles (CuNPs) from aqueous extract of Capparis spinosa $\mathrm{L}$. fruit. Their effects on liver function and hematological parameters in mice were evaluated.

Materials and Methods: The green synthesis of CuNPs by means of C. spinosa extract was achieved. Ultraviolet-visible spectroscopy, fourier transform infrared (FTIR) spectroscopy, scanning electron microscopy (SEM), and energy dispersive X-ray spectroscopy were used to identify the synthesized nanoparticles. BALB/c mice were orally administrated CuNPs at doses of 1000, 2000, and $5000 \mu \mathrm{g} / \mathrm{kg}$ for 2 weeks. Later, the effects of CuNPs on liver function in the treated mice were evaluated by measuring the serum levels of enzymes such as alanine aminotransferase, aspartate aminotransferase, alkaline phosphatase, and bilirubin as well as hematological parameters including hemoglobin, hematocrit, white blood cell, red blood cell, and platelet counts.

Results: A maximum peak at wavelength $414 \mathrm{~nm}$ confirmed the biosynthesis of CuNPs. FTIR spectrum analysis revealed that the factor groups shaped a coating extract on the surface of the nanoparticles. SEM images demonstrated a particle size between 17 and $41 \mathrm{~nm}$. Although some liver enzymes and hematological parameters increased with increasing dose of extract, there was no significant difference ( $p>0.05$ ) between oral administrations of CuNPs at doses of 1000,2000 , and $5000 \mu \mathrm{g} / \mathrm{kg}$ and the control group.

Conclusion: The findings revealed that CuNPs biosynthesized from aqueous extract of $C$. spinosa fruit have no toxic effects on the liver functions and hematological parameters of mice. However, more studies are needed for evaluation of the hepatoprotective effects of CuNPs.
\end{abstract}

Key words: Nanoparticles, copper, liver, hematology, Capparis spinosa, BALB/c mice

ÖZ

Amaç: Bu çalıșma Capparis spinosa L. meyvesinin sulu ekstresinden elde edilen bakır nanopartiküllerinin (CuNP) yeșil sentezi üzerindedir. Bunların karaciğer işlevleri ve hematolojik parametreler üzerine etkileri farelerde değerlendirilmiștir.

Gereç ve Yöntemler: CuNP'lerin C. spinosa ekstresinden eldesi sağlanmıştır. Fourier dönüșümlü kızı̈ötesi (FTIR) spektroskopisi, taramalı elektron mikroskobu (SEM) ve enerji dağıtıcı X-ışını spektroskopisi ile sentez edilen nanopartiküller belirlenmiștir. BALB/c farelere oral olarak 2 hafta boyunca 1000, 2000 ve $5000 \mu \mathrm{g} / \mathrm{kg}$ dozlarda CuNP uygulanmıştır. Sonrasında, uygulama yapılan farelerde CuNP'lerin karaciğer işlevleri üzerine etkisi alanin aminotransferaz, aspartat aminotransferaz, alkalin fosfataz ve bilirubin ölçülerek karaciğer işlevleri ve hemoglobin, hematokrit, beyaz kan hücreleri, kırmızı kan hücreleri ve trombosit sayıları belirlenerek hematolojik parametreleri ölçülmüștür.

Bulgular: 414 nm'deki maksimum pik CuNP'lerin biyosentezini göstermiştir. FTIR spectrum analizi faktör gruplarının nanopartiküllerin yüzeyinde bir kaplama ekstresine şekil verdiğini göstermiştir. SEM resimleri partikül boyutlarının 17 ve $41 \mathrm{~nm}$ arasında olduğunu göstermiştir. Her ne kadar karaciğer enzimleri ve hematolojik parametreler artan ekstre dozuyla artsa da, CuNP'lerin 1000, 2000 ve 5000 pg/kg dozlarda oral uygulaması ve kontrol grubu arasında belirgin bir değişiklik görülmemiștir ( $p>0,05)$.

*Correspondence: E-mail: armokazemi@gmail.com, Phone: +986633120150 ORCID-ID: orcid.org/0000-0002-8522-1093

Received: 25.04.2019, Accepted: 27.06.2019

OTurk J Pharm Sci, Published by Galenos Publishing House. 
Sonuç: Bu bulgular C. spinosa meyvesinin sulu ekstresinden elde edilen CuNP'lerin farelerde karaciğer işlevleri ve hematolojik parametreler üzerinde toksik etkilerinin olmadığını göstermiştir. Ancak, CuNP'lerin hepatoprotektif etkilerinin değerlendirilmesi için daha çok çalıșmaya ihtiyaç vardır. Anahtar kelimeler: Nanopartiküller, bakır, karaciğer, hematoloji, Capparis spinosa, BALB/c fare

\section{INTRODUCTION}

Nanotechnology is one of the most useful technologies and it can be applied in many areas including food and nutrition, biomedical science, gene transmission, energy science, electronics, and the space industry. In particular, this technology is implemented in the treatment of cancer, allergies, inflammation, diabetes, and other diseases.

There are various physical and chemical methods for the production of nanoparticles, and they are still being investigated for the purpose of obtaining particles with a certain size and lower toxicity. ${ }^{2}$ Green synthesis is considered a new approach to prevent the production of undesired or unsafe by products via reliable, maintainable, and eco-favorable synthesis techniques. Between the current green procedures of synthesis of nanoparticles, use of plant extracts is an appropriate and easy method to harvest nanoparticles on a large scale relative to bacteria and/or fungi mediated synthesis. ${ }^{2,3}$ Recent studies have also shown that the synthesis of metal nanoparticles using plant extracts, i.e. green synthesis, has some benefits such as low cost and low toxic effects for large-scale production. ${ }^{2-4}$

Copper $(\mathrm{Cu})$ is one of the most useful elements in medical science because of its numerous anti-inflammatory, anticancer, analgesic, and antimicrobial effects. ${ }^{5}$ In recent years, it has been proven that, because of their high surface-to-volume ratio, Cu nanoparticles (CuNPs) are extremely reactive and simply interact with other particles, leading to a wide range of biological activities. ${ }^{5-7}$

Previous reviews on laboratory animals have demonstrated that the liver is considered the key target tissue of drug toxicity. Hence, assessing the function of this organ is a very important method to determine drug toxicity. ${ }^{8}$ Nowadays, one of the main criteria to determine liver damage is measuring serum levels of enzymes such as alanine aminotransferase (ALT), aspartate aminotransferase (AST), alkaline phosphatase (ALP), and bilirubin. ${ }^{9-11}$ It has been reported that oral consumption of some medicinal agents may affect the hematological parameters and result in anemia, neutropenia, and thrombocytopenia; therefore, it is necessary to evaluate the effects of novel medicinal drugs by measuring hematological parameters. ${ }^{10}$ Accordingly, the present study examined the green synthesis of CuNPs from Capparis spinosa fruit extract and evaluated their effects on liver function and hematological parameters in mice.

\section{MATERIALS AND METHODS}

\section{Green synthesis of copper nanoparticles}

Fruits of $C$. spinosa were collected from rural areas in western Iran and then were extracted by percolation procedure by means of methanol (80\%) for 3 days at room temperature..$^{2}$ In the next step, the green synthesis of CuNPs was performed according to a method described elsewhere. Briefly, $75 \mathrm{~mL}$ of the obtained extract was added to $100 \mathrm{~mL}$ of $0.01 \mathrm{M} \mathrm{Cu}$ sulfate solution. After stirring, it was kept at $60^{\circ} \mathrm{C}$ for 1 day. In the next step, to remove all impurities, it was centrifuged twice at 12.000 rpm for $20 \mathrm{~min}$. Nanoparticles started to deposit when the color of the solution changed from green to amber yellow. The synthesized nanoparticles were heat treated in an oven at $60^{\circ} \mathrm{C}$ for further analyses.

\section{Ultraviolet-visible (UV-Vis) spectroscopy analysis}

Transformation of the $\mathrm{Cu}$ ions to CuNPs was shown by the surface plasmon resonance (SPR) of the CuNPs. For this purpose, $0.3 \mathrm{~mL}$ of the specimens was diluted with $3 \mathrm{~mL}$ of normal saline and studied via UV-Vis spectrum analysis by means of a spectrophotometer (JENWAY 6405) in the range of 300-700 nm. ${ }^{13}$

\section{Fourier transform infrared (FTIR) spectroscopy}

After pouring and mixing the obtained samples and potassium bromide granules together in a ratio of 1 to 100 (1/100 ratio) and compacting them into tablets, FTIR (model Nicolet 32 ) analysis was carried out in the range of $400-4000 \mathrm{~cm}^{-1}$ and with the resolution of $1-4 \mathrm{~cm}^{-1}$.

\section{Scanning electron microscope (SEM)}

To obtain the characteristics of the synthesized nanoparticles, electron microscopy (Mira3, Czech Republic) with $15 \mathrm{kV}$, magnification of $10 \mathrm{x}$, and resolution of $1 \mathrm{~nm}$ was performed.

\section{Animals and study design}

A total of 32 male BALB/c mice weighing 25-30 g were provided by the Tehran Pasteur Institute and kept in light/ dark cycles of $12: 12 \mathrm{~h}$. The room temperature was $22 \pm 2^{\circ} \mathrm{C}$ and the mice had ad libitum access to water and food. They were placed in laboratory conditions 30 min before the start of the experiment. The ethical approval required for this study (IR. LUMS.REC.1398.247) was issued by the Ethics Committee of Lorestan University of Medical Sciences, Lorestan, Iran. The mice tested were assigned to the following four groups:

Group i: Received normal saline orally for 14 days;

Group ii: Received CuNPs at a concentration of $1000 \mu \mathrm{g} / \mathrm{kg}$ orally for 14 days;

Group iii: Received CuNPs at a concentration of $2000 \mu \mathrm{g} / \mathrm{kg}$ orally for 14 days;

Group iv: Received CuNPs at a concentration of $5000 \mu \mathrm{g} / \mathrm{kg}$ orally for 14 days.

\section{Sample collection}

On day 15 of the experiments, the mice were anesthetized by ketamine-xylazine followed by collection of blood samples from each mouse after the heart was opened. The collected blood samples were put into tubes with or without anticoagulant 
to process their clots and then their sera were separated by centrifugation at 5000x g for $10 \mathrm{~min}$.

\section{Evaluation of the serum liver enzymes}

To determine the hepatoprotective effects of CuNPs, different clinical chemistry parameters related to liver function such as AST, ALT, ALP, and bilirubin (direct and total) were assayed by commercial diagnostics kits (Roche, Germany).10,15

\section{Hematological parameters}

To assess the effects of CuNPs on hematological studies, total collected blood was put into tubes containing ethylenediaminetetraacetic acid. Next, hematological parameters including hemoglobin, hematocrit, white blood cell, red blood cell, and platelet (PLT) counts were measured by Sysmex (KX-21, Japan).

\section{Statistical analysis}

SPSS version 17.0 (SPSS Inc., Chicago, IL, USA) was used to analyze the obtained data. One-Way ANOVA and Tukey's posthoc test were performed to assess the difference between the experimental groups and p<0.05 was considered statistically significant.

\section{RESULTS}

\section{Ultraviolet-visible spectrum analysis}

The results obtained showed that the highest peak of the synthesized CuNPs was found at a wavelength of $414 \mathrm{~nm}$. The characteristic of the resonance band of the SP happened for CuNPs at $414 \mathrm{~nm}$ wavelength (Figure 1).

\section{Fourier transform infrared analysis}

The FTIR findings revealed that the biomolecules in the extract decreased the Cu sulfate solution. The bands at 3380, 2928, 1741, 1604, 1400, 1050, and 1271 were indexed to the $\mathrm{O}-\mathrm{H}$ stretching of alcohol and phenol, $\mathrm{C}-\mathrm{H}$ stretching of the aliphatic group, $\mathrm{C}=\mathrm{O}$ stretching of ester carbonyl, $\mathrm{C}=\mathrm{C}$ stretching of the aromatic ring, and $\mathrm{C}-\mathrm{O}$ stretching of ester, respectively (Figure 2).

\section{Scanning electron microscope analysis}

Following the confirmation of the synthesized nanoparticles through color modification and Vis-UV and FTIR, the

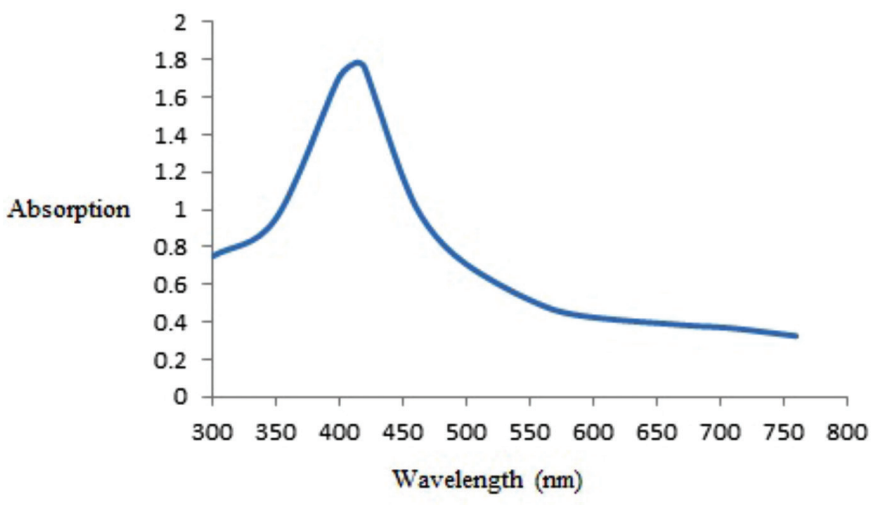

Figure 1. The absorption spectrum of synthesized copper nanoparticles characterization of nanoparticles was determined with SEM. As shown in Figure 1, the synthesized CuNPs represent spherical morphology, whereas the size of the particles was between 17 and $41 \mathrm{~nm}$ (Figure 3).

\section{Hepatoprotective effects of CuNPs}

Table 1 shows the results of hepatoprotective effects on serum biochemical parameters in mice receiving CuNPs at doses of 1000,2000 , and $5000 \mu \mathrm{g} / \mathrm{kg}$ for 14 days. As can be seen, although these parameters increased with increasing doses of extract, there was no statistically significant difference ( $p>0.05$ ) between oral administrations of CuNPs at doses of 1000, 2000, and $5000 \mu \mathrm{g} / \mathrm{kg}$ and the control group.

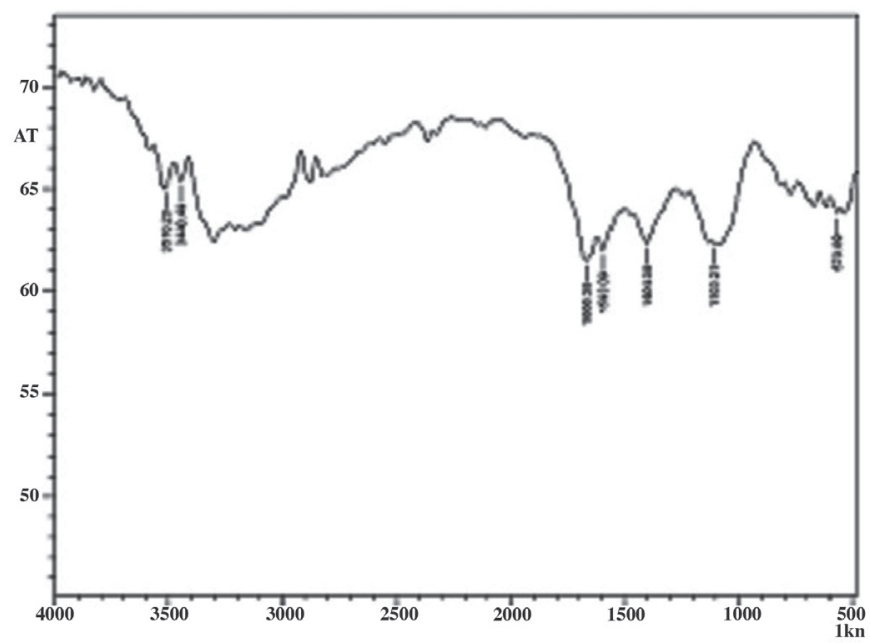

Figure 2. The FTIR spectrum of synthesized copper nanoparticles FTIR: Fourier transform infrared

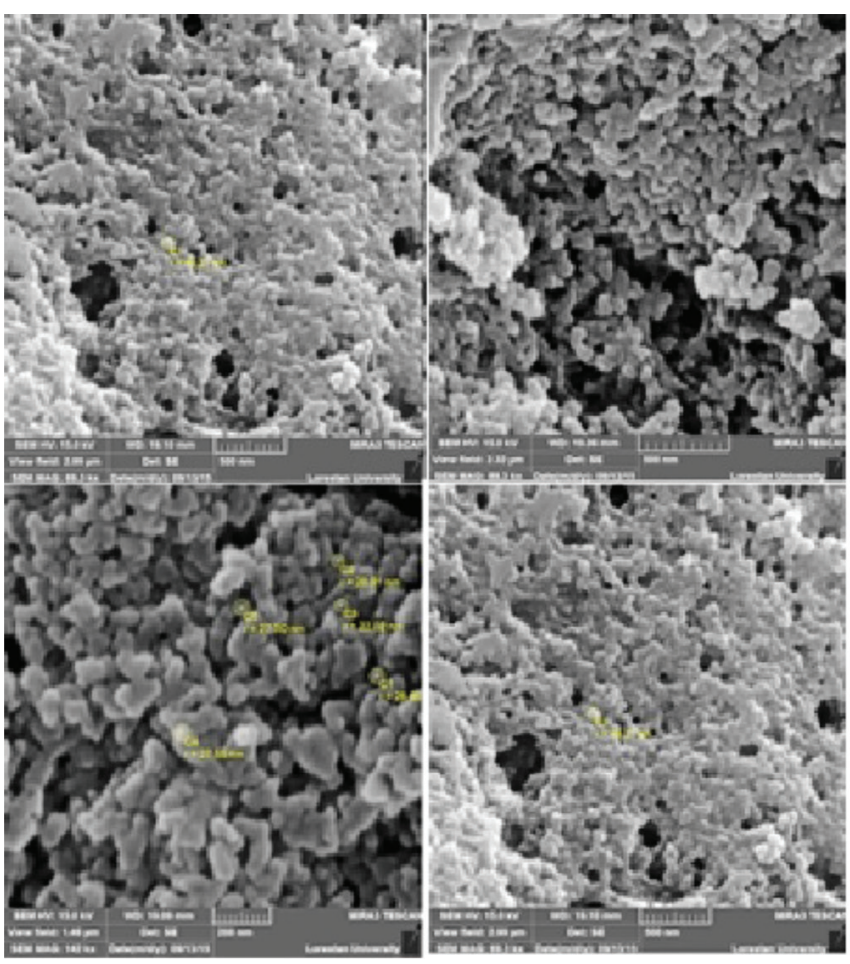

Figure 3. Scanning electron microscope images of copper nanoparticles synthesized using aqueous extract of Capparis spinosa fruit $\mathrm{x} 10000$ 


\section{Effect on hematological parameters}

As shown in Table 2, following the oral administrations of CuNPs at the employed doses of 1000, 2000, and $5000 \mu \mathrm{g} /$ $\mathrm{kg}$ for 14 days, there was no significant difference $(p<0.05)$ between hematological parameters compared with the control group.

\begin{tabular}{|c|c|c|c|c|}
\hline $\begin{array}{l}\text { Clinical } \\
\text { biochemistry } \\
\text { parameters }\end{array}$ & AST (U/L) & ALT (U/L) & ALP (U/L) & TB \\
\hline Control & $130.6 \pm 8.15$ & $38.3 \pm 4.31$ & $132.3 \pm 8.15$ & $0.12 \pm 0.03$ \\
\hline $\begin{array}{l}\text { CuNPs } \\
(1000 \mu g / k g)\end{array}$ & $142.4 \pm 6.15$ & $40.3 \pm 3.15$ & $139.6 \pm 6.5$ & $0.15 \pm 0.05$ \\
\hline $\begin{array}{l}\text { CuNPs } \\
(2000 \mu \mathrm{g} / \mathrm{kg})\end{array}$ & $138.8 \pm 5.51$ & $39.3 \pm 2.51$ & $142.3 \pm 5.01$ & $0.14 \pm 0.04$ \\
\hline $\begin{array}{l}\text { CuNPs } \\
(5000 \mu \mathrm{g} / \mathrm{kg})\end{array}$ & $144.3 \pm 8.15$ & $42.7 \pm 4.36$ & $144.6 \pm 6.15$ & $0.17 \pm 0.05$ \\
\hline
\end{tabular}

CuNPs: Copper nanoparticles, ALT: Alanine aminotransferase, ALP: Alkaline phosphatase, AST: Aspartate aminotransferase, TB: Total bilirubin

Table 2. Hematology parameters in whole blood of mice following oral administration of CuNPs for 2 weeks. The results are given as mean \pm standard deviation

\begin{tabular}{lllll} 
Parameters & \multicolumn{3}{l}{ Curcuma longa essential $(\mu \mathrm{g} / \mathrm{kg})$} & Control \\
\cline { 2 - 4 } & 1000 & 2000 & 5000 & \\
\hline RBC $\left(\times 10^{6} / \mu \mathrm{L}\right)$ & $3.7 \pm 0.13$ & $3.2 \pm 0.25$ & $2.9 \pm 0.41$ & $3.4 \pm 0.3$ \\
\hline HGB $(\mathrm{g} / \mathrm{dL})$ & $11.2 \pm 0.6$ & $10.5 \pm 1.15$ & $10.1 \pm 0.6$ & $11.3 \pm 0.45$ \\
\hline Hct $(\%)$ & $33.7 \pm 3.1$ & $32.12 \pm 2.15$ & $30.4 \pm 2.51$ & $32.6 \pm 2.18$ \\
\hline WBC $\left(\times 10^{3} / \mu \mathrm{L}\right)$ & $3.3 \pm 0.45$ & $2.7 \pm 0.26$ & $3.1 \pm 0.25$ & $2.8 \pm 0.2$ \\
\hline PLT $\left(\times 10^{3} / \mu \mathrm{L}\right)$ & $187 \pm 15$ & $193 \pm 13$ & $175 \pm 11$ & $184 \pm 17$ \\
\hline
\end{tabular}

CuNPs: Copper nanoparticles, RBC: Red blood cell, HGB: Hemoglobin, Hct: Hematocrit, WBC: White blood cell, PLT: Platelet

\section{DISCUSSION}

In recent years, studies in the field of nanotechnology have demonstrated that physical and chemical procedures to create nanoparticles, despite having exceptional biological activities, due to having some restrictions like toxicity, are replaced by a number of new methods such as green synthesis.' Today, considering that nanoparticles are broadly used by a large proportion of the world's population to treat some diseases, it is necessary to measure the toxicity of these products by different methods. Since recent studies have shown that CuNPs possess a wide range of biological activities, ${ }^{16}$ we decided to evaluate their toxicity and hepatoprotective effects in mice.

Recent studies have shown that liver enzyme measurement is one of the key diagnostic tests to evaluate the liver function and also inflammations and damage such as hepatitis and cirrhosis. ${ }^{8,10}$ CuNPs, because of their high surface-to-volume ratio, are extremely reactive and simply interact with other particles.
Therefore, they have numerous biological activities. ${ }^{17,18}$ It has been proven that some medications can cause irreparable complications through reducing white and red blood cells and the number of blood PLTs; thus, it is necessary to evaluate the effects of novel medicinal drugs by measuring hematological parameters. ${ }^{19}$

Based on the results of the present study, after oral administration of mice with CuNPs at doses of 1000, 2000, and $5000 \mu \mathrm{g} / \mathrm{kg}$ for 14 days, although some parameters increased with increasing dose of extract, there was no statistically significant difference ( $p>0.05$ ) between oral administrations of CuNPs at these doses and the control group. Moreover, no statistically significant difference $(p<0.05)$ was observed in hematological parameters between mice treated with CuNPs and the control group.

Considering the study of the hepatoprotective effects of nanoparticles and similar to our findings, Zhang et al. ${ }^{20}$ demonstrated that silver nanoparticles synthesized using Rhizophora apiculata were effective in protecting the liver from harm induced by carbon tetrachloride.

Bhuvaneswari et al. ${ }^{21}$ reported that increased enzymatic levels of AST, ALT, ALP, and bilirubin by $\mathrm{CCl}_{4}$ returned to normal when treated with silver nanoparticles synthesized using fruit extract of Embilica officinalis, indicating potent hepatoprotective effects of these nanoparticles. In the study conducted by Eftekhari et al.22, quercetin nanoparticles showed remarkable hepatoprotective activity via decreasing levels of AST, ALT, and ALP. Ghosh and Gomes ${ }^{23}$ also recently showed that gold nanoparticles synthesized by Trigonella foenum-graecum extract significantly normalized the increased enzymatic levels of AST, ALT, ALP, and bilirubin induced by $\mathrm{CCl}_{4}$, which indicated the hepatoprotective potential of these nanoparticles.

In the present study, we applied $C$. spinosa to facilitate the synthesis of CuNPs. Next, we synthesized CuNPs that were spherical and ranging from 17 and $41 \mathrm{~nm}$ in size. To date, a wide range of plants such as Syzygium aromaticum, Nerium oleander, Citrus medica Linn., Capparis zeylanica, Gloriosa superba L., and Vitis vinifera have been applied in the biosynthesis of CuNPs. However, identifying the plant's capacity as biological material for the synthesis of nanoparticles in full detail requires more investigations. $5,6,17,24-27$

\section{CONCLUSION}

The findings revealed that CuNPs biosynthesized from aqueous extract of $C$. spinosa fruit have no toxic effect on the liver of the studied mice, and no significant toxicity was observed in their hematological parameters. However, more studies need to be done for evaluation of the hepatoprotective effect of CuNPs.

\section{ACKNOWLEDGMENTS}

The authors are thankful to the staff of Razi Herbal Medicines Research Center, Khorramabad, Iran as well as the staff of Bam University of Medical Sciences, Bam, Iran.

Conflicts of interest: No conflict of interest was declared by the authors. The authors alone are responsible for the content and writing of the paper. 


\section{REFERENCES}

1. Boisseau P, Loubaton B. Nanomedicine, nanotechnology in medicine et nanotechnologies pour la medecine. Comptes Rendus Physique. 2011;12:620-636.

2. Mano PM, Karunai SB, John Paul JA. Green synthesis of silver nanoparticles from the leaf extracts of Euphorbia hirta and Nerium indicum. Digest J Nanomat Biostruct. 2011;6:869-877.

3. Khatami M, Pourseyedi S. Phoenix dactylifera (date palm) pit aqueous extract mediated novel route for synthesis high stable silver nanoparticles with high antifungal and antibacterial activity. IET Nanobiotechnol. 2015;9:184-190

4. Khatami M, Mortazavi SM, Kishani-Farahani Z, Amini A, Amini E, Heli H. Biosynthesis of silver nanoparticles using pine pollen and evaluation of the antifungal efficiency. Iran J Biotechnol. 2017;15:95-101.

5. Saranyaadevi K, Subha V, Ravindran RS, Renganathan S. Synthesis and caharacterization of copper nanoparticle using Capparis Zeylanica leaf extract. Int J Chem Tech Res. 2014;6:4533-4541.

6. Naika HR, Lingaraju K, Manjunath K, Kumar D, Nagaraju G, Suresh D, Nagabhushana $\mathrm{H}$. Green synthesis of $\mathrm{CuO}$ nanoparticles using Gloriosa superba L. extract and their antibacterial activity. J Taibah Uni Sci. 2015;9:7-12.

7. Angrasan J, Subbaiya R. Biosynthesis of copper nanoparticles by Vitis vinifera leaf aqueous extract and its antibacterial activity. Int J Curr Microbiol Appl Sci. 2014;3:768-774.

8. Mahmoudvand H, Fallahi S, Mahmoudvand H, Shakibaie M, Harandi MF, Dezaki ES. Efficacy of Myrtus communis L. to Inactivate the Hydatid Cyst Protoscoleces. J Invest Surg. 2016;29:137-143.

9. Fallahi S, Beyranvand M, Mahmoudvand $\mathrm{H}$, Nayebzadeh $\mathrm{H}$, Kheirandish F, Jahanbakhsh S. Chemical composition, acute and subacute toxicity of Satureja khuzestanica essential oil in mice. J Res Pharm. 2017;21:515521.

10. Mahmoudvand $H$, Oliaei RT, Mirbadie SR, Kheirandish F, Kareshk AT, Ezatpour B, Mahmoudvand H. Efficacy and Safety of Bunium Persicum (Boiss) to Inactivate Protoscoleces during Hydatid Cyst Operations. Surg Infect (Larchmt). 2016;17:713-719.

11. Mahmoudvand $H$, Mahmoudvand $H$, Oliaee RT, Kreshk AT, Mirbadie SR, Aflatoonian MR. In vitro Protoscolicidal Effects of Cinnamomum zeylanicum Essential Oil and Its Toxicity in Mice. Pharmacogn Mag. 2017;13(Suppl 3):S652-S657.

12. Shiravand M, Ebrahimi K, Mahmoudvand H. Biosynthesis of copper nanoparticles using aqueous extract of Capparis spinosa fruit and investigation of its antibacterial activity. Marmara Pharm J. 2017;21:866871.

13. Khatami M, Mortazavi SM, Kishani-Farahani Z, Amini A, Amini E, Heli H. Biosynthesis of Silver Nanoparticles Using Pine Pollen and Evaluation of the Antifungal Efficiency. Iran J Biotechnol. 2017;15:95-101.
14. Soltani Nejad M, Khatami M, Shahidi Bonjar GH. Extracellular synthesis gold nanotriangles using biomass of Streptomyces microflavus. IET Nanobiotechnol. 2016;10:33-38.

15. Mahmoudvand H, Kheirandish F, Dezaki ES, Shamsaddini S, Harandi MF. Chemical composition, efficacy and safety of Pistacia vera (var. Fandoghi) to inactivate protoscoleces during hydatid cyst surgery. Biomed Pharmacother. 2016;82:393-398.

16. Murthy SK. Nanoparticles in modern medicine: State of the art and future challenges.Int J Nanomedicine. 2007;2:129-41.

17. Gopinath M, Subbaiya R, Selvam MM, Suresh D. Synthesis of copper nanoparticles from Nerium oleander leaf aqueous extract and its antibacterial activity. Int J Curr Microbiol Appl Sci. 2014;3:814-818.

18. Katha U, and Gajera H. Synthesis of copper nanoparticles by two different methods and size comparison. Int J Pharm Bio Sci. 2014;5:533-540.

19. Muriithi NJ, Maina GS, Mugendi NM, Maina MB, Kiambi MJ, kelvin JK, Umar A, John MK, Ann NW, YA A, Piero NM, Eliud NNM. Determination of Hematological Effects of Methanolic Leaf Extract of S. incanum in Normal Mice. Pharm Anal Acta. 2015;6:10. doi:10.4172/21532435.1000429

20. Zhang $H$, Jacob JA, Jiang Z, Xu S, Sun K, Zhong Z, Varadharaju N, Shanmugam A. Hepatoprotective effect of silver nanoparticles synthesized using aqueous leaf extract of Rhizophora apiculata. Int J Nanomedicine. 2019;14:3517-3524.

21. Bhuvaneswari R, Chidambaranathan N, Jegatheesan K. Hepatoprotective effect of Embilica officinalis and its silver nanoparticles against ccl4 induced hepatotoxicity in Wistar albino rats. Digest Journal of Nanomaterials and Biostructures. 2014;9:223-235.

22. Eftekhari A, Ahmadian E, Panahi-Azar V, Hosseini H, Tabibiazar M, Dizaj SM. Hepatoprotective and free radical scavenging actions of quercetin nanoparticles on aflatoxin B1-induced liver damage: in vitro/ in vivo studies. Artif Cells, Nanomed Biotechnol. 2018;46:411-420.

23. Ghosh S, Gomes A. Hepatoprotective efficacy of gold nanoparticle synthesized by green method using Trigonella foenum-graecum seed extract. Transl Med (Sunnyvale). 2016; 6:4.

24. Subhankari I, Nayak PL. Synthesis of copper nanoparticles using Syzygium aromaticum (Cloves) aqueous extract by using green chemistry. World J Nano Sci Technol. 2013;2:14-17.

25. Shende S, Ingle AP, Gade A, Rai M. Green synthesis of copper nanoparticles by Citrus medica Linn. (Idilimbu) juice and its antimicrobial activity. World J Microbiol Biotechnol. 2015;31:865-873.

26. Janakiraman M. Protective efficacy of silver nanoparticles synthesized from Silymarin on cisplatin induced renal oxidative stress in albino rat. Inter J Appl Pharm. 2018;10:110-116.

27. Nafari A, Cheraghipour K, Sepahvand M, Shahrokhi G, Gabal E, Mahmoudvand $H$. Nanoparticles: New agents toward treatment of leishmaniasis. Parasite Epidemiol Control. 2020;10:e00156. 